\title{
Spatial distribution of epibenthic molluscs on a sandstone reef in the Northeast of Brazil
}

\author{
Martinez, AS. ${ }^{a *}$, Mendes, $L F^{a}{ }^{a}$ and Leite, TS. $^{b}$ \\ aLaboratório do Oceano, Departamento de Botânica, Ecologia e Zoologia, \\ Universidade Federal do Rio Grande do Norte - UFRN, CEP 59072-970, Natal, RN, Brazil \\ ${ }^{b}$ Laboratório de Biologia Pesqueira, Departamento de Oceanografia e Limnologia, \\ Universidade Federal do Rio Grande do Norte - UFRN, Via Costeira s/n Mãe Luiza, CEP 59014-100, Natal, RN, Brazil \\ *e-mail: aline_oceano@yahoo.com.br \\ Received March 30, 2011 - Accepted May 31, 2011 - Distributed May 31, 2012
}

(With 5 figures)

\begin{abstract}
The present study investigated the distribution and abundance of epibenthic molluscs and their feeding habits associated to substrate features (coverage and rugosity) in a sandstone reef system in the Northeast of Brazil. Rugosity, low coral cover and high coverage of zoanthids and fleshy alga were the variables that influenced a low richness and high abundance of a few molluscan species in the reef habitat. The most abundant species were generalist carnivores, probably associated to a lesser offer and variability of resources in this type of reef system, when compared to the coral reefs. The results found in this study could reflect a normal characteristic of the molluscan community distribution in sandstone reefs, with low coral cover, or could indicate a degradation state of this habitat if it is compared to coral reefs, once that the significantly high coverage of fleshy alga has been recognized as a negative indicator of reef ecosystems health.

Keywords: molluscs, epifauna, sandstone reef, substrate cover, Brazil.
\end{abstract}

\section{Distribuição espacial de moluscos epibentônicos em um recife arenítico no Nordeste do Brasil}

\begin{abstract}
Resumo
O presente estudo investigou a distribuição, a abundância e os hábitos alimentares de moluscos epibentônicos associados à cobertura e à rugosidade do substrato, em um sistema recifal arenítico no Nordeste do Brasil. A rugosidade, a baixa cobertura de corais e a alta cobertura de zoantídeos e algas frondosas foram as variáveis que influenciaram na baixa riqueza e na alta abundância de poucas espécies de moluscos no habitat recifal. As espécies mais abundantes foram classificadas em carnívoras generalistas, provavelmente associadas à baixa oferta e variabilidade de recursos nesse tipo de sistema recifal, quando comparado a recifes coralíneos. Os resultados encontrados neste estudo podem estar refletindo características normais para a distribuição dos moluscos em recifes areníticos, com baixa cobertura de coral, ou podem estar indicando um estado de degradação desse habitat, quando comparado aos recifes de corais, uma vez que a cobertura significativa de algas frondosas vem sendo reconhecida como um indicador negativo quanto à saúde dos ecossistemas recifais.
\end{abstract}

Palavras-chave: moluscos, epifauna, recife arenítico, cobertura do substrato, Brasil. 


\section{Introduction}

Most studies on molluscan distribution in reef systems have been conducted on true coral reefs (Salvat, 1967, 1972; Taylor, 1968, 1971; Thomassin and Ganelon, 1977; Sheppard, 1984; McClanahan, 1989, 1990; Díaz et al., 1990; Augustin et al., 1999; Wells, 2000; Zuschin et al., 2000, 2001), ecosystems that show deep calcareous formations with an extensive coral cover and diversity. The wide variety of taxa and the life habits of molluscs in these ecosystems are closely linked to coral cover and diversity (Zuschin et al., 2000).

In Brazil, most of the reefs present tiny calcareous formations that grow on sandstone rocks whose main bioconstructors are encrusting calcareous algae, vermetid molluscs and few corals (Maida and Ferreira, 1997; Castro and Pires, 2001). These reefs cover an extensive stretch of coast and are ecologically unique ecosystems that show a different reef composition and formation from many other coral reefs worldwide (Leão and Dominguez, 2000).

Despite the low coral richness of Brazilian reefs (18 species), these environments are economically important for fishing and ecotourism activities in Brazil, as well as for protecting the coastline (Maida and Ferreira, 1997; Leão and Dominguez, 2000; Castro and Pires, 2001). Among the marine animals exploited in the Northeast of Brazil are molluscs such as octopus, squid and bivalves for human consumption, as well as gastropods, whose shells are sold as souvenirs. In addition to their importance as a fishing resource, molluscs are ecologically important in these environments. They represent important predator species such as the octopus, that feeds on many reef invertebrates (Boyle and Rodhouse, 2005), in addition to being a group whose species has different feeding habits on coral reefs which include carnivores, herbivores, filter feeders, detritivores, omnivores, etc (Reed and Mikkelsen, 1987; Zuschin et al., 2001).

Molluscs are also widely used as bioindicators in reef ecosystems, since they occupy a variety of ecological niches in hard substrate environments (Zuschin et al., 2001), where composition and life habits are related to environmental and substrate variations (Augustin et al., 1999; Zuschin et al., 2001). Thus, data about composition and spatial distribution of species in these ecosystems may help in monitoring anthropic disturbances in the marine environment (Richmond, 1993; Dayton, 1994).

Studies conducted in protected marine areas can also assess the natural structure of communities and, compared with non-protected areas, may provide information about the effects of anthropic impacts in marine coastal environments (Carr, 2000). It was observed that in protected fishing areas, the populations of some commercially exploited molluscs increased, whereas in non-protected areas the abundance of non-exploited molluscs also increased, owing to the decreased number of predators (McClanahan, 1990; Ashworth et al., 2004).

Despite their previously described importance, little is known about the distribution and relationship of molluscs with sandstone reef habitats. In Northeast Brazil, the main occurrence area of sandstone reefs in the country, knowledge of molluscan composition and distribution in the reef systems is scarce (Matthews, 1967; Matthews and Rios, 1969, 1974; Furtado-Ogawa, 1970; Mathews and Kempf, 1970; Oliveira, 1971; Matthews-Cascon et al., 1989).

Considering the importance of molluscs in reef environments and the need for information about their distribution and relationship with sandstone reef habitats, the aim of the present study was: to assess the spatial distribution of epibenthic molluscs in different habitats of a sandstone reef and investigate the relation of species occurrence and feeding habits with substrate cover.

\section{Material and Methods}

\subsection{Study area}

The study was conducted on the Maracajaú reef $\left(05^{\circ} 38^{\prime} \mathrm{S}\right.$ and $\left.35^{\circ} 25^{\prime} \mathrm{W}\right)$, located $7 \mathrm{~km}$ from the Maracajaú beach, Maxaranguape city, in the State of Rio Grande do Norte, Northeast of Brazil. Maracajaú reef belongs to the Coral Reef Protected Area (APARC), created in 2001 (Amaral et al., 2005) (Figure 1).The Maracajaú reef is a fishing area with intense underwater tourism activity in the southern part of the reefs (Amaral et al., 2005). Its formation is characterized by sandstone patch reefs composed of slightly thick calcareous constructions (Laborel and Kempf, 1967; Laborel, 1970; Maida and Ferreira, 1997).

The reef complex is $9 \mathrm{~km}$ long by $2 \mathrm{~km}$ wide, with crests between 0 and $3 \mathrm{~m}$ deep at low tide (Maida and Ferreira, 1997; Amaral et al., 2005). The complex also encompasses an area of seagrass and a sandy bottom in the most protected region of the reefs. Water turbidity is generally high at low tide, but high visibility predominates between October and March. Water temperature varies throughout the year from 22 (winter) to $27^{\circ} \mathrm{C}$ (summer) (Maida and Ferreira, 1997).

\subsection{Data collection}

Twenty-three sampling sites were established and georeferenced along the reef complex using Amaral (2002) classification in relation to bottom composition. Three habitats were defined: reef (patch reefs), sandy bottom and seagrass bottom (Figure 1).

Initially, 22 exploratory dives were made between August 2006 and February 2007 to record the species inhabiting the study area (qualitative analysis). This survey was conducted randomly in each habitat, where all the individuals observed with the naked eye on the substrate were collected. The taxa of the molluscs collected were identified and classified into 6 groups in terms of their feeding habits (carnivores, coralivores, herbivores, filter feeders, deposit feeders and scrap feeders) according to specialized bibliographies (Morton, 1968; Carriker and Zandt, 1972; Vermeij, 1978; Hughes and Hughes, 1981; Matthews-Cascon et al., 1989; Rios, 1994; Pequeno and 


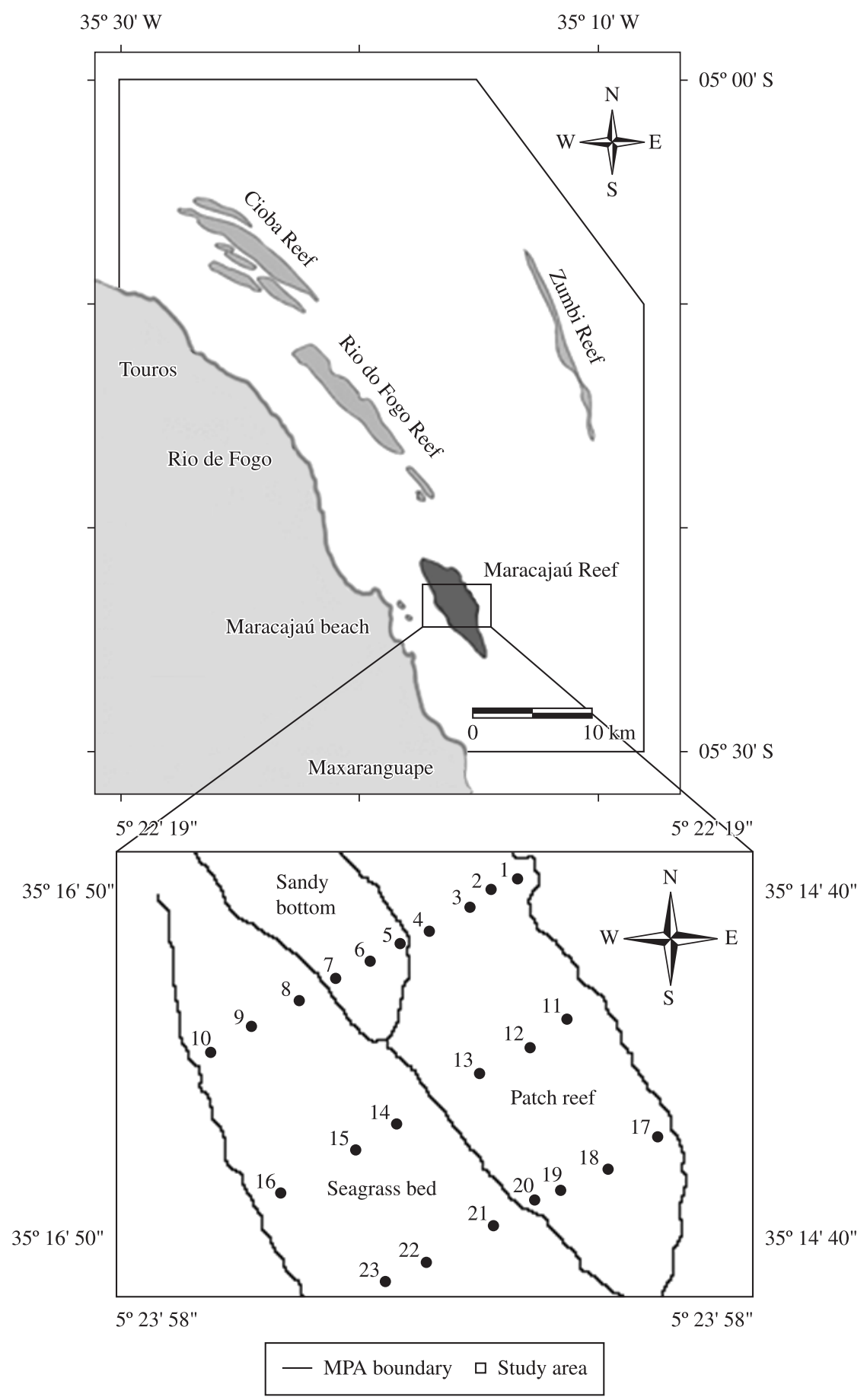

Figure 1. Study area with the sampling sites in detail.

Matthews-Cascon, 2001; Simone, 2002; Meirellis, 2005; Bezerra et al., 2006).

In March 2007, 23 additional dives were undertaken to determine distribution and species abundance using quantitative samplings. Species quantification focused on individuals larger than $0.5 \mathrm{~cm}$, in order to minimize the risks of undersampling. The belt transect was the sampling technique used, which has been considered efficient for recording the heterogeneity of environments (Krebs, 1999; Nadon and Stirling, 2006). Each site consisted of three belt transects of $10 \mathrm{~m}^{2}(10 \times 1 \mathrm{~m})$ parallel to each other. A record was obtained for each square meter of transect using a $1 \times 1 \mathrm{~m}$ square (Adjeroud, 2000).

In each square, the number of individuals per taxon was quantified and the general substrate rugosity (Figure 2) was estimated according to the method proposed by Gratwicke 


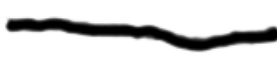

0

Without rugosity

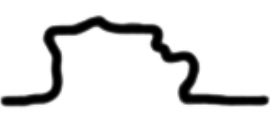

2

Medium rugosity
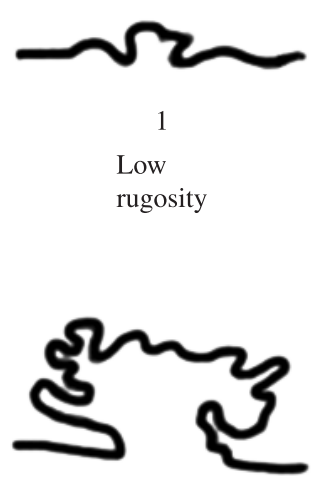

3

High rugosity
Figure 2. Visual topographic estimate of the substrate in each quadrat.

and Speight (2005). The substrate cover (coral, zoanthids, sand, mud, rock, seagrass and functional form groups of macroalgae (Littler and Littler, 1983)) was quantified attributing weights between 0 and 3 for each category, according to occurrence (Figure 3 ).

\subsection{Statistical analysis}

The normality (Kolmogorov-Smirnov test) and heterocedasticity (Levene's test) of species richness and density data were tested to attend the premises of ANOVA analysis. After that, species richness data and square root transformation of the density data $(x=\sqrt{x}, \operatorname{Zar}(1999))$ of the molluscs obtained in quantitative samplings were compared among the habitat sampling sites (mean value of molluscan data per transect) and between reef and seagrass habitats (mean value of molluscan data per site), using one-way ANOVA. The Tukey test was conducted for significantly different results. The data collected on the sandy bottom were used only for qualitative assessment of the habitat, due to the low number of individuals recorded (3).

In order to determine distribution patterns and spatial variation of the molluscs in reef and seagrass habitats, the mean value of molluscan density data from each site was used to perform multivariate analysis. A similarity matrix was generated using the Bray-Curtis index, with taxon data and the number of individuals per taxon. This was followed by MDS (multidimensional scaling) ordination analysis (Clarke and Warwick, 2001).

The mean values of substrate rugosity and substrate cover data of each site were submitted to PCA (Principal Component Analysis) exploratory analysis, using the Euclidean Distance Index (Clarke and Warwick, 2001) to determine substrate variations among sampling sites. A similarity matrix was generated and the clusters found in PCA were tested using ANOSIM analysis (Clarke and Warwick, 2001), showing the possible differences and significance of the clusters.

The BIO-ENV analysis (Clarke and Warwick, 2001) was performed from the similarity matrices built with

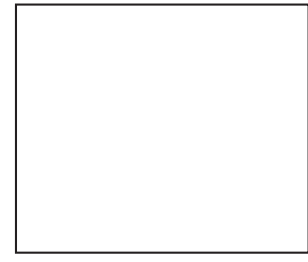

0

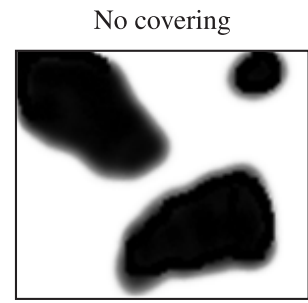

2

Medium covering

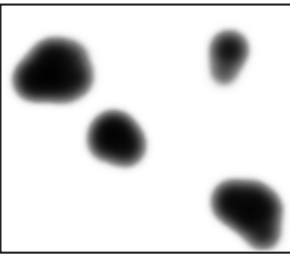

Low covering

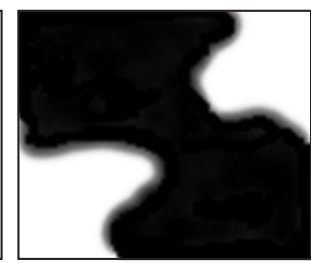

3

High covering
Figure 3. Visual estimate of substrate cover in each square.

molluscan fauna composition and environmental data to determine the substrate variables that influence molluscan distribution (variation in richness and abundance) in reef and seagrass habitats.

\section{Results}

Forty five mollusc species were recorded in the study area (qualitative and quantitative samplings), distributed into the classes Gastropoda (37 spp.), Bivalvia (7 spp.) and Cephalopoda (1 sp.) (Table 1). The largest number of species was recorded in the reef habitat (39), while 20 species were found in the seagrass habitat and only 2 on the sandy bottom.

During the quantitative samplings, 164 individuals were registered among 7 species in the reef habitat and 19 individuals distributed into 9 species in the seagrass habitat. Low species density was observed in both habitats, and 4 species (Engina turbinella (Kiener, 1835), Trachypollia nodulosa (Adams, 1845), Leucozonia nassa (Gmelin, 1791) and one gastropod from the Vermetidae family) were more abundant and frequent in the reef habitat (Table 2).

Assessing the feeding habits of molluscs, the highest number of carnivorous molluscs in the reef habitat was found (3 spp. and 135 individuals). The other individuals, less representative on the reefs, were classified as suspensivores (1 sp. and 20 individuals), herbivores (2 spp. and 6 individuals) and only 1 coralivore species, the gastropod Coralliophila caribaea (Abbott, 1958), with low occurrence (3 individuals). In the seagrass habitats, there were recorded carnivores (4 spp. and 6 individuals), filter feeders ( $2 \mathrm{spp}$. and 2 individuals), herbivores ( $1 \mathrm{sp}$. and 5 individuals), deposit feeders ( $1 \mathrm{sp}$. and 3 individuals) and scrap feeders (1 sp. and 3 individuals).

The molluscan richness in the reef habitat showed a significant variation between site 2 (Table 3 ), with the 
Table 1. Registered molluscs at Maracajaú Coral Reef in the different habitats and their corresponding feeding habits.

\begin{tabular}{|c|c|c|c|c|}
\hline Taxon & $\begin{array}{c}\text { Reef } \\
\text { habitat }\end{array}$ & $\begin{array}{c}\text { Seagrass } \\
\text { bed }\end{array}$ & $\begin{array}{c}\text { Sandy } \\
\text { bottom }\end{array}$ & $\begin{array}{c}\text { Feed } \\
\text { habit }\end{array}$ \\
\hline \multicolumn{5}{|l|}{ GASTROPODA } \\
\hline Turbo canaliculatus (Hermann, 1781) & & $\mathrm{X}$ & & Herbivore \\
\hline Astraea phoebia (Röding, 1798) & $\mathrm{X}$ & $\mathrm{X}$ & & Herbivore \\
\hline Cerithium atratum (Born, 1778) & $\mathrm{X}$ & $\mathrm{X}$ & $\mathrm{X}$ & Deposit feeder \\
\hline Cerithium eburneum (Bruguiere,1792) & $\mathrm{X}$ & $\mathrm{X}$ & & Deposit feeder \\
\hline Hipponix antiquatus (Linnaeus, 1767) & $\mathrm{X}$ & & & Filter feeder \\
\hline Hipponix subrufus (Lamarck, 1819) & $\mathrm{X}$ & & & Filter feeder \\
\hline Vermetidae (Rafinesque, 1815) & $\mathrm{X}$ & & & Filter feeder \\
\hline Cypraea zebra (Linnaeus, 1758) & $\mathrm{X}$ & & & Herbivore \\
\hline Natica cayennensis (Recluz,1870) & $\mathrm{X}$ & & & Carnivorous \\
\hline Polinices hepaticus (Roding, 1798) & $\mathrm{X}$ & $\mathrm{X}$ & & Carnivorous \\
\hline Sinum perspectivum (Say, 1831) & $\mathrm{X}$ & & & Carnivorous \\
\hline Cassis tuberosa (Linnaeus, 1758) & $\mathrm{X}$ & & & Carnivorous \\
\hline Favartia cellulosa (Conrad, 1846) & & $\mathrm{X}$ & & Carnivorous \\
\hline Trachypollia nodulosa (Adams, 1845) & $\mathrm{X}$ & & & Carnivorous \\
\hline Coralliophila caribaea (Abbott, 1958) & $\mathrm{X}$ & & & Coralivorous \\
\hline Engina turbinella (Kiener, 1835) & $\mathrm{X}$ & & & Carnivorous \\
\hline Pisania pusio (Linnaeus, 1758) & $\mathrm{X}$ & & & Carnivorous \\
\hline Anachis lyrata (Sowerby, 1832) & $\mathrm{X}$ & & & Carnivorous \\
\hline Anachis coseli (Díaz \& Mittnacht, 1989) & $\mathrm{X}$ & & & Carnivorous \\
\hline Columbella mercatoria (Linnaeus, 1758) & $\mathrm{X}$ & & & Herbivore \\
\hline Nassarius vibex (Say, 1822) & & $\mathrm{X}$ & & Scrap feeder \\
\hline Latirus infundibulum (Gmelin, 1791) & $\mathrm{X}$ & & & Carnivorous \\
\hline Leucozonia nassa (Gmelin, 1791) & $\mathrm{X}$ & & & Carnivorous \\
\hline Leucozonia ocellata (Gmelin, 1791) & $\mathrm{X}$ & & & Carnivorous \\
\hline Pleuroploca aurantiaca (Lamarck, 1816) & $\mathrm{X}$ & $\mathrm{X}$ & & Carnivorous \\
\hline Olivella nivea (Gmelin, 1791) & $\mathrm{X}$ & & & Carnivorous \\
\hline Oliva scripta (Lamarck, 1811) & $\mathrm{X}$ & $\mathrm{X}$ & & Carnivorous \\
\hline Vexillum exiguum (Adams, 1845) & $\mathrm{X}$ & & & Carnivorous \\
\hline Clathrodrillia sólida (Adams, 1850) & $\mathrm{X}$ & & & Carnivorous \\
\hline Pilsbryspira albomaculata( d’Orbigny, 1842) & $\mathrm{X}$ & & & Carnivorous \\
\hline Crassispira apicata (Reeve, 1845) & $\mathrm{X}$ & $\mathrm{X}$ & & Carnivorous \\
\hline Terebra doello-juradoi (Carcelles, 1953) & $\mathrm{X}$ & $\mathrm{X}$ & & Carnivorous \\
\hline Conus jaspideus (Gmelin, 1791) & $\mathrm{X}$ & & $\mathrm{X}$ & Carnivorous \\
\hline Voluta ebraea (Linnaeus, 1758) & & $\mathrm{X}$ & & Carnivorous \\
\hline Micromelo undatus (Bruguière, 1792) & & $\mathrm{X}$ & & Carnivorous \\
\hline Bulla striata (Bruguière, 1792) & $\mathrm{X}$ & $\mathrm{X}$ & & Carnivorous \\
\hline Aplysia dactylomela (Rang, 1828) & $\mathrm{X}$ & & & Herbivore \\
\hline \multicolumn{5}{|l|}{ BIVALVIA } \\
\hline Arca imbricata (Bruguière, 1789) & $\mathrm{X}$ & & & Filter feeder \\
\hline Anadara notabilis (Röding, 1798) & $\mathrm{X}$ & $\mathrm{X}$ & & Filter feeder \\
\hline Anadara brasiliana (Lamarck, 1819) & $\mathrm{X}$ & $\mathrm{X}$ & & Filter feeder \\
\hline Pinctada imbricata (Röding, 1798) & $\mathrm{X}$ & & & Filter feeder \\
\hline Atrina seminuda (Lamarck, 1819) & & $\mathrm{X}$ & & Filter feeder \\
\hline Codakia orbicularis (Linnaeus, 1758) & $\mathrm{X}$ & $\mathrm{X}$ & & Filter feeder \\
\hline Divaricella quadrisulcata (d'Orbigny, 1842) & $\mathrm{X}$ & $\mathrm{X}$ & & Filter feeder \\
\hline \multicolumn{5}{|l|}{ CEPHALOPODA } \\
\hline Octopus sp. (Cuvier, 1797) & $\mathrm{X}$ & $\mathrm{X}$ & & Carnivorous \\
\hline Total species number & 39 & 20 & 2 & \\
\hline
\end{tabular}


Table 2. Abundance, mean density (individuals $\mathrm{m}^{-2}$ ) and frequency of occurrence (FO - \%) of the quantified molluscs in the reef habitat and seagrass bed at Maracajaú Coral Reef. The total abundance and density in each habitat is on the end of the table.

\begin{tabular}{|c|c|c|c|c|c|c|}
\hline \multirow{2}{*}{ Taxon } & \multicolumn{3}{|c|}{ Reef habitat } & \multicolumn{3}{|c|}{ Seagrass bed } \\
\hline & Abundance & Density & FO & Abundance & Density & FO \\
\hline Astraea phoebia & & & & 5 & 0.02 & 44 \\
\hline Cerithium atratum & & & & 3 & 0.01 & 22 \\
\hline Vermetidae & 20 & 0.07 & 64 & & & \\
\hline Trachypollia nodulosa & 25 & 0.08 & 64 & & & \\
\hline Coralliophila caribaea & 3 & 0.01 & 9 & & & \\
\hline Engina turbinella & 85 & 0.27 & 91 & & & \\
\hline Columbella mercatoria & 3 & 0.009 & 18 & & & \\
\hline Nassarius vibex & & & & 3 & 0.010 & 11 \\
\hline Leucozonia nassa & 25 & 0.08 & 82 & & & \\
\hline Oliva scripta & & & & 1 & 0.004 & 11 \\
\hline Voluta ebraea & & & & 1 & 0.004 & 11 \\
\hline Micromelo undatus & & & & 1 & 0.004 & 11 \\
\hline Aplysia dactylomela & 3 & 0.01 & 18 & & & \\
\hline Atrina seminuda & & & & 1 & 0.004 & 11 \\
\hline Laevicardium brasilianum & & & & 1 & 0.004 & 11 \\
\hline Octopus sp. & & & & 3 & 0.01 & 22 \\
\hline Total & 164 & 0.5 & & 19 & 0.07 & \\
\hline
\end{tabular}

Table 3. Richness (species number), abundance (total individuals number) and density (mean of individuals $\mathrm{m}^{-2} \pm \mathrm{SD}$ ) of the quantified molluscs in each site of the reef habitat and seagrass bed at Maracajaú Coral Reef. There are the total values $($ mean $\pm \mathrm{SD})$ at the end of the sites for each habitat.

\begin{tabular}{ccccc}
\hline & Sites & Richness & Abundance & Density \\
\hline & 1 & 2 & 2 & $0.07 \pm 0.06$ \\
2 & 7 & 27 & $0.90 \pm 0.53$ \\
3 & 4 & 12 & $0.40 \pm 0.17$ \\
Reef habitat & 4 & 14 & $0.43 \pm 0.15$ \\
& 11 & 3 & 13 & $0.43 \pm 0.32$ \\
& 12 & 3 & 16 & $0.53 \pm 0.32$ \\
& 13 & 3 & 7 & $0.23 \pm 0.21$ \\
& 17 & 4 & 12 & $0.40 \pm 0.26$ \\
& 18 & 3 & 41 & $1.37 \pm 1.25$ \\
& 19 & 4 & 16 & $0.53 \pm 0.40$ \\
Seagrass bed & 20 & 4 & $0.13 \pm 0.23$ \\
& 8 & 1 & 2 & $0.49 \pm 0.37$ \\
\hline $9.55 \pm 1.37$ & 1 & 3 & $0.07 \pm 0.12$ \\
& 10 & 1 & 1 & $0.13 \pm 0.06$ \\
& 14 & 3 & 5 & $0.03 \pm 0.06$ \\
& 15 & 1 & 1 & $0.17 \pm 0.21$ \\
& 16 & 1 & 1 & $0.03 \pm 0.06$ \\
& 21 & 1 & 1 & $0.03 \pm 0.06$ \\
& 22 & 2 & 2 & $0.03 \pm 0.06$ \\
23 & $1.33 \pm 0.87$ & $1.78 \pm 1.48$ & $0.07 \pm 0.06$ \\
& Total & & $0.13 \pm 0.06$ \\
& & & & $0.06 \pm 0.05$ \\
\hline
\end{tabular}


highest value (7 spp.), and sites 1 and 20 (2 spp.) (ANOVA, $F=2.7517 ; \mathrm{df}=22 ; \mathrm{p}<0.05)$. Significant differences were also found between the mean density (ANOVA, $\mathrm{F}=2.5001$; $\mathrm{df}=22 ; \mathrm{p}<0.05)$, with a higher value obtained at site 18 (M:1.37 $\pm 1.25 \mathrm{SD})$ compared to sites $1(\mathrm{M}: 0.07 \pm 0.06 \mathrm{SD})$ and 20 (M:0.13 $\pm 0.23 \mathrm{SD}$ ) (Table 3 ). In the seagrass habitat no differences were observed among the sampling sites, for both richness $(\mathrm{p}>0.05)$ and molluscan density $(p>0.05)$. A comparison of both habitats showed that the reef habitat had greater molluscan richness (M:2.12 \pm 1.17 SD) (ANOVA, F = 17.1380; = 18; $\mathrm{p}<0.001$ ) and density

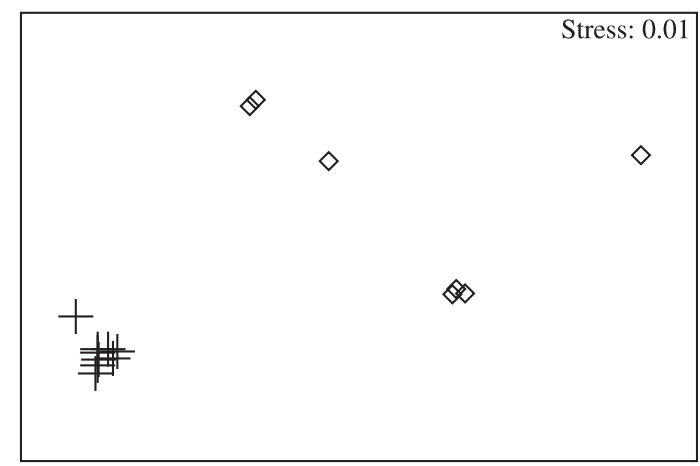

Figure 4. MDS ordination biplot of molluscan faunal similarity among sites of the reef (plus symbol) and seagrass (lozenge) habitats.
$(\mathrm{M}: 0.49 \pm 0.37 \mathrm{SD})($ ANOVA, $\mathrm{F}=19.8736 ; \mathrm{df}=18$ $\mathrm{p}<0.001$ ) than in the seagrass habitat (Table 3 ).

The reef habitat sites showed greater similarity in species distribution than among seagrass sites, which showed a more heterogeneous distribution, according to the results obtained by ordination analysis (MDS) (Figure 4).

Assessment of substrate cover using PCA showed that the sampling sites had 4 clusters ( 2 on the reefs and 2 at seagrass sites) in the Maracajaú reef complex (Figure 5). These clusters were statistically significant among themselves, according to ANOSIM results, in both reef $\left(\mathrm{R}_{1,2}=0.926\right.$; $\mathrm{p}<0,01)$ and seagrass habitats $\left(\mathrm{R}_{3,4}=0.969 ; \mathrm{p}<0.05\right)$.

In general, the reef habitat was characterized with a wide coverage of fleshy algae (mainly brown algae that belongs to the Order Dictyotales and the green algae Caulerpa racemosa ((Forsskal) J. Agardh 1873)) and zoanthids (mainly Palythoa caribaeorum (Duchassaing and Michelotti, 1860)), and to a lesser extent with coral cover. Group 1 of the reef habitat (Figure 5) was characterized by large fleshy alga cover, zoanthids and coral with less rugosity. Group 2 was also characterized by large zoanthid and fleshy alga cover, differing from the first group in the greater abundance of articulated calcareous algae. Groups 3 and 4 correspond to the sampling sites in the seagrass habitats, where group 3 was characterized as having densities of seagrass with sandy sediment and group 4 with muddy sediment.

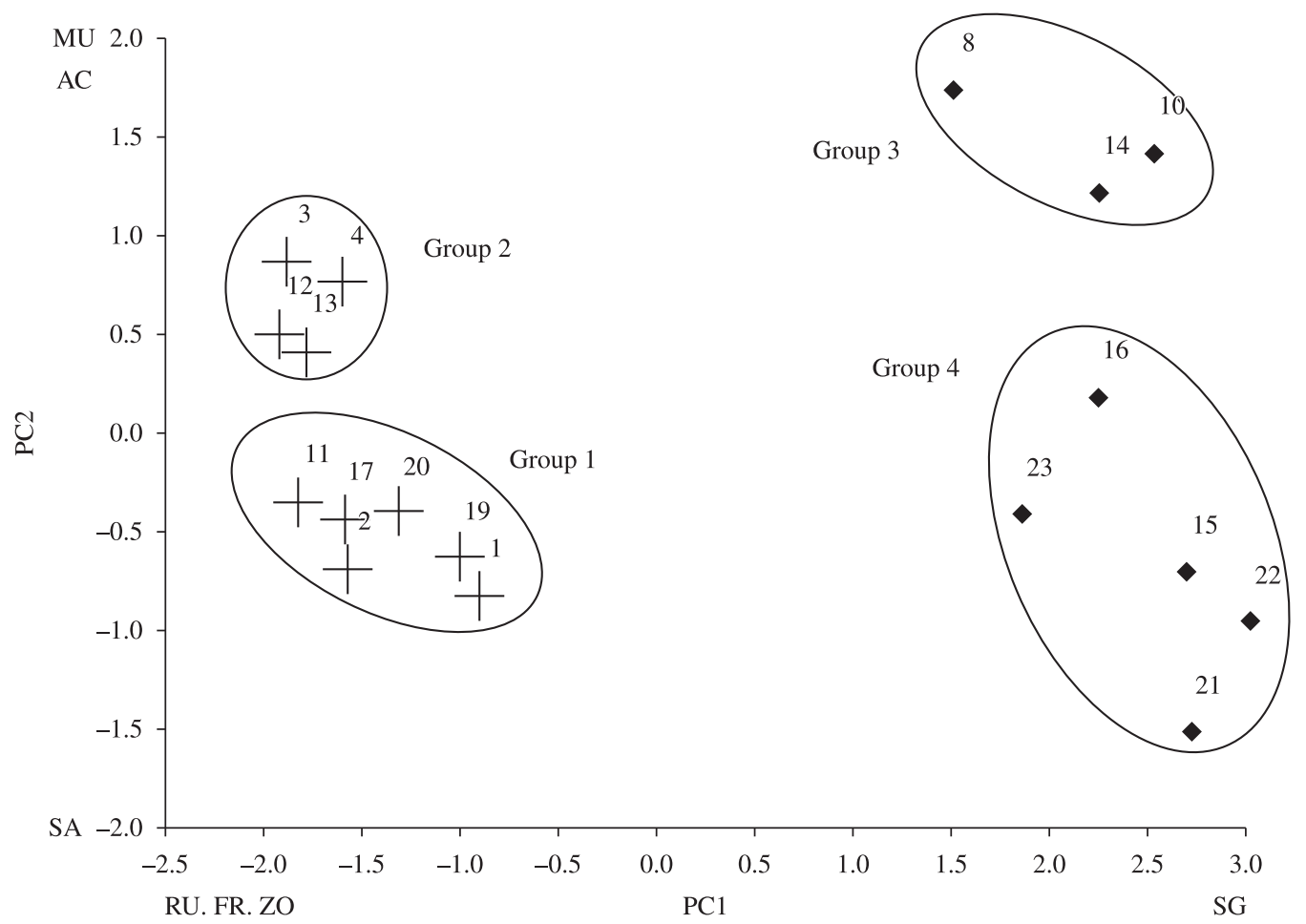

Figure 5. PCA ordination biplot of sample substrate from the reef (plus symbol) and seagrass (lozenge) sites. PC1 (x-axis) and PC2 (y-axis) together account for $86.6 \%$ of the total sample variability. RU = rugosity, $\mathrm{ZO}=$ zoanthid, $\mathrm{AC}=$ articulated calcareous algae, $\mathrm{TU}=$ turf algae, $\mathrm{FR}=$ fleshy algae, $\mathrm{SA}=$ sand, $\mathrm{MU}=$ mud and $\mathrm{SG}=$ seagrass. 
Table 4. BIO-ENV analysis showing associations between 10 environmental variables* and molluscan community structure for the different habitats. $\mathrm{R}$ is the correlation coefficient.

\begin{tabular}{lcccc}
\hline & Best & R & Best combination & R \\
\hline Maracajaú Reef system & SG & 0.77 & RU, SA, SG, FR & 0.76 \\
Reef habitat & RU & 0.37 & RU, CR, FR, ZO & 0.49 \\
Seagrass bed & SA, MU & 0.05 & SA, MU, FR & 0.04 \\
\hline
\end{tabular}

$* \mathrm{RU}=$ rugosity, $\mathrm{CO}=$ coral, $\mathrm{ZO}=$ zoanthid, $\mathrm{NR}=$ nude rock, $\mathrm{CR}=$ crustose algae, $\mathrm{AC}=$ articulated calcareous algae, $\mathrm{FR}=$ fleshy algae, $\mathrm{SA}=$ sand, $\mathrm{MU}=$ mud e $\mathrm{SG}=$ seagrass.

Seagrass and frondose algae cover, rugosity and sandy substrate were the main factors that influenced molluscan distribution throughout the Maracajaú reef system according to BIO-ENV analysis (Table 4).

Rugosity, crustose algae, fleshy alga and zoanthids cover were the main factors associated to the distribution (richness and abundance) of the species present in the reef habitat. The most abundant epibenthic mollusc species (E. turbinella, T. nodulosa, L. nassa) was widely distributed among the sampling sites (see frequency of occurrence in Table 2), reflecting the relationship between the malacofauna and the general characteristic of the substrate found on the reef.

A very low correlation was found in the seagrass habitat results and variables, however sand and mud were the factors that respond to the distribution of mollusc species in the seagrass habitat. In group 1, species restricted to the sandy substrate such as the gastropods Oliva scripta (Lamarck, 1811) and Voluta ebraea (Linnaeus, 1758) and the cephalopod Octopus sp were found. In group 2, molluscs were observed restricted to the sandy substrate such as the gastropods Cerithium spp. and Nassarius vibex (Say, 1822).

\section{Discussion}

The low molluscan richness found in this study (45 spp.) compared to true coral reefs may be related to the characteristics of the sandstone reef, which has low coral density and extensive covers of zoanthids and fleshy algae. According to studies on reef environments, high molluscan richness is associated to coral cover (Díaz et al., 1990; Zuschin et al., 2000). Thus, the characteristics of the reef substrate of Maracajaú probably does not provide as many food resources and habitats to the mollusc species as coral reefs do, thereby decreasing the number of mollusc species that feed on corals or depend on them for survival.

The positive relationship between molluscan richness and the presence of corals can be observed when the value found on the Maracajaú reefs (45 spp.) is compared with another Brazilian reef environment, the Abrolhos reefs (293 spp. of molluscs) (Dutra et al., 2005), which contain the highest coral richness in the country (18 spp. versus 4 spp. in Maracajaú). This reef, which has greater richness and large coral covers, probably favors the occurrence of a large number of mollusc species, including the rarely represented coralline species in this study.
The only coralivorous gastropod species found in Maracajaú (C. caribaea) lives on the coral Favia sp. according to Rios (1994), which occurs rarely on these reefs. In a recent study (unpublished data) conducted in a similar reef system and near the Maracajaú reefs, a larger number of individuals of $C$. caribaea were observed, as well as greater coral cover (Favia sp. and other corals). These results could reinforce the positive relationship between diversity and coral cover and mollusc species.

High rugosity is one of the positive characteristics found on the Maracajaú reefs. It is related to the increase in molluscan richness and abundance when comparing to the seagrass habitat. This variable provides more structural complexity to the reef habitat, leading to the formation of microhabitats and cavities that provide shelter for many molluscs (Konh and Leviten, 1976; Díaz et al., 1990). On coral reefs, rugosity may be even greater due to the threedimensional structure provided by the corals themselves.

The large cover of zoanthids, mainly P. caribeaorum, is considered a negative factor when associated with molluscan richness. The results found in the study conducted by Pèrez et al. (2005) showed a low number of epibenthic mollusc species associated to this zoanthid. One of the possible explanations for this negative relationship is the low structural complexity offered by this zoanthid, which forms extensive and flat dense covers with a high production of mucus.

Fleshy algae in large covers could also influence the low molluscan richness in Maracajaú, once this algae category is considered unpalatable to many herbivorous animals (Littler and Littler, 1983; Hay et al., 1987; Hay and Fenical, 1988; Steneck and Dethier, 1994). In general, fleshy algae are not palatable to large herbivores such as fish and sea urchins in tropical habitats, meanwhile small herbivores (mesograzers) such as amphipods, isopods and polychaetas often feed on these macroalgae (see review of Duffy and Hay, 1990). The mainly fleshy algae registered in this study were the green algae $C$. racemosa and brown algae of the Order Dictyotales. The former is an algae avoided by many herbivores due to its chemical and morphological defense, even so ascoglossan gastropods (very small sea slugs) feed on them, which sequester their chemical defenses (see review of Duffy and Hay, 1990). On the other hand, studies on chemical defense of Brazilian tropical algae demonstrated that algae species of the Order Dictyotales (Pereira et al., 2000; Pereira et al., 2002), the other most recorded algae in this study, have 
chemical defenses against small herbivorous gastropods and crustaceans avoiding herbivory.

Therefore, the main macroalgae recorded in this study could avoid the occurrence of molluscan herbivores at Maracajaú by chemical and morphological defenses, although more studies are needed to investigate this process. Moreover, the great cover of fleshy algae on the reef could prevent the growth and settlement of reef building corals (Done, 1992; Hughes, 1994; McCook, 1999, McCook et al., 2001 ; McManus and Polsenberg, 2004), which could indirectly influence the low molluscan richness on Maracajaú's reef.

In relation to molluscan density, the low value for the species is a common characteristic in coral reef systems (McClanahan, 1990, 2002; Zuschin et al., 2001). The higher abundance of few species found on the Maracajaú reef, a result also observed on Caribbean reefs, may be associated to environmental stress (McClanahan, 2002). Additionally, the fact that the lower the number of species that use the same ecological niche is, the lower the competition among them is, also may have favored the increased abundance of dominant and more generalist species.

The hypothesis of favoring generalist molluscs may be strengthened when the species found in this study were classified according to the feeding strategy. The most abundant and most widely distributed epibenthic species (E. turbinella, T. nodulosa and L. nassa) were classified as generalist carnivores, feeding on crustaceans, polychaetes and other molluscs (Rios, 1994).

Zoanthids and fleshy algae, therefore, could be directly or indirectly related to the high abundance of few species and low richness of molluscs on the Maracajaú reefs. Fleshy algae are described in the literature as indicators of reef degradation, shown by the decline in the coral cover (Done, 1992; Hughes, 1994; McCook, 1999; McCook et al., 2001; Littler et al., 2006) and could indicate a poor state of conservation on the Maracajaú reef, reflected in the results of this study for the molluscan assemblages. Earlier investigations conducted by Laborel (1970) about 4 decades ago on the Maracajaú reefs may show evidence of the existence of environmental alterations on these reefs. The author characterized this environment as having large covers of the coral Siderastrea stellata, incrusting calcareous algae and vermetid molluscs, in which the latter was found in relative low density.

This change in substrate cover may account for the altered coral reef community structure, which would result in loss of local biodiversity (Done, 1992; Hughes, 1994; McClanahan et al., 2002; Folk et al., 2004) and increased abundance in dominant generalist species. This substrate alteration may be correlated to the fishing activity that has taken place in this region for many years, which would explain the large fleshy alga cover in the entire reef area due to the lack of herbivore fish.

In the seagrass habitat, there was no evident abundance of few species, such as is found on the reefs, but rather a more balanced distribution between the numbers of individual species. The variation in sediment (sandy and muddy) between the sites was an important factor in molluscan distribution within this habitat, given that these types of sediment are related to different ecological niches occupied by the molluscs (Jones et al., 1990; Zuschin and Honegger, 1998). The low values for molluscan density and richness in the profiles of seagrass and sandy bottom habitats probably reflect the behavior of many individuals that habitually bury in the substrate and are not visible to the naked eye. Additional studies on the infauna of seagrass and sandy bottoms should significantly increase molluscan diversity in the reef system of Maracajaú, given that this group is characteristic of unconsolidated sea bottoms (Jones et al., 1990; Zuschin and Honegger, 1998).

Therefore, biological and physical substrate cover may contribute to molluscan distribution on the reef habitats studied. These include rugosity, low coral cover, and high zoanthid and fleshy alga cover, whereas physical factors, such as type of sediment, were important in the variation of molluscan distribution in the seagrass habitat.

Finally, the results found in this study could indicate a damaged reef when compared to coral reefs, although, on the other hand, they could represent a natural characteristic of sandstone reefs. This type of reef system is still poorly understood and its structure is different from hard shores like coral reefs and rocky shores. The present study was an initial investigation about the distribution of molluscan fauna and its relationship with substrata on sandstone reefs - an ecosystem that encompasses an extensive area of Brazilian coast and is an important natural resource for inhabitants of these areas. Hence, further studies must be developed in order to examine carefully the distribution patterns of molluscan fauna on these reef systems and the factors that influence them, which will enable us to evaluate the impacts of human activities (e.g. fishery and tourism) over the structure of benthic communities.

Acknowledgements - This study was supported by CAPES funding. We would like to thank PROMAR/IDEMA and Maracajaú Divers for the logistical support and to IDEA WILD for donating field equipment. I would like to thank Professor Helena Mathews Cascon (UFCE) for helping with species identification and Professor Alexandre Vasconcellos (UFRN) for helping with statistical analysis.

\section{References}

ADJEROUD, M., 2000. Zonation of macrobenthic communities along two bays in an insular coral reef ecossystem (Moorea, French Polynesia). Life Sciences, vol. 323, p. 305-313.

AMARAL, RF., 2002. Mapeamento da Área de Proteção Ambiental dos Recifes de Corais - Fase Exploratória. Natal: UFRN/IDEMA. 50 p. Relatório interno.

AMARAL, RF., FEITOZA, BM., ATTAYDE, JL., ARANTES, SV., BATISTA, DS., COSTA-NETO, LX., MENDES, LF., MARTIN, FS., SILVA, IB., SORIANO, EM. and ZIGGMOND, M., 2005. Diagnóstico Ambiental da Área de Uso Turístico Intensivo (AUTI) no Parracho de Maracajaú. Natal: UFRN/IDEMA. 128 p. Relatório interno. 
ASHWORTH, JS., ORMONDA, FFG. and STURROCK, HT., 2004. Effects of reef-top gathering and fishing on invertebrate abundance across take and no-take zones. Journal of Experimental Marine Biology and Ecology, vol. 303, p. 221- 242. http://dx.doi. org/10.1016/j.jembe.2003.11.017

AUGUSTIN, D., RICHARD, G. and SALVAT, B., 1999. Longterm variation in mollusk assemblages on a coral reef, Moorea, French Polynesia. Coral Reefs, vol. 18, p. 293-296. http://dx.doi. org/10.1007/s003380050197

BEZERRA, LEA., CARVALHO, AFU. and MATTHEWSCASCON, H., 2006. Biologia populacional da lesma-do-mar Aplysia dactylomela (Rang, 1828) em duas praias do estado do Ceará. Arquivos de Ciências do Mar, vol. 39, p. 91-85.

BOYLE, P. and RODHOUSE, P., 2005. Cephalopods: Ecology and fisheries. Oxford: Blackwell. 452 p.

CASTRO, CB. and PIRES, DO., 2001. Brazilian coral reefs: what we already know and what is still missing. Bulletin of Marine Science, vol. 69, no. 2, p. 357-371.

CARR, MH., 2000. Marine protected areas: challenges and opportunities for understanding and conserving coastal marine ecosystems. Environmental Conservation, vol. 27, no. 2, p. 106109. http://dx.doi.org/10.1017/S0376892900000151

CARRIKER, MR. and ZANDT, DV., 1972. Predatory behavior of a shell-boring muricid gastropod. In WINN, H.E. and OLLA, BL. (Eds.). Behavior of Marine Animals: Current perspectives in research. New York: Plenum Press. vol. 1: Invertebrates, p. 157-244.

CLARKE, KR. and WARWIICK, RM., 2001. Changes in marine communities: an approach to statistical analysis and interpretation. 2nd ed. Plymouth: PRIMER-E. 172 p.

DAYTON, PK., 1994. Community landscape: scale and stability in hard bottom marine communities. In GILLER, PS., HILDREW, AG. and RAFFAELI, DG. (Eds.). Aquatic ecology: Scale, pattern and progress. Oxford: Blackwell Scientific Publications. p. 289-332.

DÍAZ, JM., ESCOBAR, LA. and VELÁSQUEZ, LE., 1990. Reef associated molluscan fauna of the Santa Marta Area, Caribbean coast of Colombia. Anales del Instituto de Investigaciones Marinas, vol. 20, p. 173-196.

DONE, TJ., 1992. Phase shifts in coral reef communities and their ecological significance. Hydrobiology, vol. 247, p. 121-132. http://dx.doi.org/10.1007/BF00008211

DUFFY, JE. and HAY, ME., 1990. Seaweeds Adaptations to Herbivory. Bioscience, vol. 40, no. 5, p. 368-375. http://dx.doi. org/10.2307/1311214

DUTRA, GF., ALLEN, GR., WERNER, T. and MCKENNA, SA. (Eds.), 2005. A Rapid Marine Biodiversity Assessment of the Abrolhos Bank, Bahia, Brazil. Washington: Conservation International. 160 p. (RAP Bulletin of Biological Assessment, n. 38).

FOLK, C., CARPENTER, S., WALKER, B., SCHEFFER, M., ELMQVIST, T., GUNDERSON, L. and HOLLING, CS., 2004. Regime shifts, resilience, and biodiversity in ecosystem management. Annual Review of Ecology and Systematics, vol. 35, p. 557-581. http://dx.doi.org/10.1146/annurev.ecolsys.35.021103.105711

FURTADO-OGAWA, E., 1970. Contribuição ao conhecimento da fauna malacológica intertidal de substratos duros no nordeste brasileiro. Arquivos de Ciências do Mar, vol. 10, no. 2, p. 193-196.
GRATWICKE, B. and SPEIGHT, MR., 2005. The relationship between fish species richness, abundance and habitat complexity in a range of shallow tropical marine habitats. Journal of Fish Biology, vol. 66, p. 650-667. http://dx.doi.org/10.1111/j.00221112.2005.00629.x

HAY, ME. and FENICAL, W., 1988. Marine plant-herbivore interactions: the ecology of chemical defense. Annual Review of Ecology and Systematics, vol. 19, p. 111-145. http://dx.doi. org/10.1146/annurev.es.19.110188.000551

HAY, ME., FENICAL, W. and GUSTAFSON, K., 1987. Chemical defense against diverse coral-reef herbivores. Ecology, vol. 68, p. 1581-1591.

HUGHES, RN. and HUGHES, HPI., 1981. Morphological and behavioural aspects of feeding in the Cassidae (Tonnacea, Mesogastropoda). Malacologia, vol. 20, no. 2, p. 385-402. PMid: 17801530

HUGHES, TP., 1994. Catastrophes, phase shifts and large-scale degradation of a Caribbean coral reef. Science, vol. 265, p. 15471551. http://dx.doi.org/10.1126/science.265.5178.1547

JONES, JP., FERRELL, DJ and SALE, PF., 1990. Spatial pattern in the abundance and structure of mollusc populations in the soft sediments of a coral reef lagoon. Marine Ecology Progress Series, vol. 62, p. 109-120. http://dx.doi.org/10.3354/meps062109

KONH, AJ. and LEVITEN, PJ., 1976. Effect of habitat complexity on population density and species richness in tropical intertidal predatory gastropod assemblages. Oecologia, vol. 25, no. 3 , p. 199-210. http://dx.doi.org/10.1007/BF00345098

KREBS, CJ., 1999. Ecological Methodology. 2nd ed. New York: Benjamin Cummings. 620 p.

LABOREL, J., 1970. Les peuplements de madreporaires dês cotes tropicales Du Bresil. Annuals of the University of Abidjan, serie E, vol. 2, no. 3, p. 1-260.

LABOREL, J. and KEMP, M., 1967. Formação de vermetos e algas calcáreas na costa do Brasil. Trabalhos do Instituto Oceanográfico da Universidade Federal de Pernambuco, vol. 7, p. 33-50.

LEÃO, ZMAN. and DOMINGUEZ, JML., 2000. Tropical Coast of Brazil. Marine Pollution Bulletin, vol. 41, p. 112-122. http:// dx.doi.org/10.1016/S0025-326X(00)00105-3

LITTLER, MM. and LITTLER, DA., 1983. Evolutionary strategies in a tropical barrier reef system: functional-form groups of marine macroalgae. Phycologia, vol. 19, p. 229-237. http:// dx.doi.org/10.1111/j.0022-3646.1983.00229.x

LITTLER, MM., LITTLER, DA. and BROOKS, BL., 2006. Harmful algae on tropical coral reefs: bottom-up eutrophication and top-down herbivory. Harmful Algae, vol. 5, p. 565-585. http:// dx.doi.org/10.1016/j.hal.2005.11.003

MAIDA, M. and FERREIRA, BP., 1997. Coral reefs of Brazil: an overview. In Proceedings of the 8nd International Coral Reef Symposium, 1997. Panama City. vol. 1, p. 263-274.

MATTHEWS, HR., 1967. Primeira contribuição ao inventário dos moluscos marinhos do nordeste brasileiro. Arquivo da Estação de Biologia Marinha da Universidade Federal do Ceará, vol. 7, no. 1 , p. $67-77$

MATTHEWS, HR. and KEMPF, M., 1970. Moluscos marinhos do norte e nordeste do Brasil II - Moluscos do Arquipélago de 
Fernando de Noronha (com algumas referências ao Atol das Rocas). Arquivos de Ciências do Mar, vol. 10, no. 1, p. 1-53.

MATTHEWS, HR. and RIOS, EC., 1969. Terceira contribuição ao inventário dos moluscos marinhos do nordeste brasileiro. Arquivo da Estação de Biologia Marinha da Universidade Federal do Ceará, vol. 9, no. 1, p. 27-35.

-, 1974. Quarta contribuição ao inventário dos moluscos marinhos do nordeste brasileiro. Arquivos de Ciências do Mar, vol. 14, no. 1, p. 47-56.

MATTHEWS-CASCON, H., MATTHEWS, HR. and KOTZIAN, CB., 1989. Os gêneros Fasciolaria Lamarck, 1799 e Leucozonia Gray,1847 no nordeste brasileiro (Mollusca: Gastropoda: Fasciolariidae). Memórias do Instituto Oswaldo Cruz, vol. 84, no. 4, p. 357-364. http://dx.doi.org/10.1590/S0074-02761989000800064

McCLANAHAN, TR., 1989. Kenyan coral reef-associated gastropod fauna: a comparison between protected and unprotected reefs. Marine Ecology Progress Series, vol. 53, p. 11-20. http:// dx.doi.org/10.3354/meps053011

-, 1990. Kenyan coral reef-associated gastropod assemblages: distribution and diversity patterns. Coral Reefs, vol. 9, p. 63-74. http://dx.doi.org/10.1007/BF00368801

-, 2002. A comparison of the ecology of shallow subtidal gastropods between western Indian Ocean and Carribean coral reefs. Coral Reefs, vol. 21, p. 399-406.

McClANAHAN, T., POLUNIN, N. and DONE, T., 2002. Ecological States and the Resilience of Coral Reefs. Conservation Ecology, vol. 6, no. 2.

McCOOK, LJ., 1999. Macroalgae, nutrients and phase shifts on coral reefs: scientific issues and management consequences for the Great Barrier Reef. Coral Reefs, vol. 18, p. 357-367. http:// dx.doi.org/10.1007/s003380050213

McCOOK, LJ., JOMPA, J. and DÍAZ-PULIDO, G., 2001. Competition between corals and algal on coral reefs: a review of evidence and mechanims. Coral Reefs, vol. 19, p. 400-417. http://dx.doi.org/10.1007/s003380000129

McMANUS, J.W. and POLSENBERG, J.F., 2004. Coral-algal phase shifts on coral reefs: ecological and environmental aspects. Progress in Oceanography, vol. 60, p. 263-279. http://dx.doi. org/10.1016/j.pocean.2004.02.014

MEIRELLIS, CO., 2005. A Biologia de Pleuroploca aurantiaca (Mollusca: Gastropoda: Fasciolariidae). Fortaleza: Universidade Federal do Ceará. 164 p.

MORTON, JE., 1968. Molluscs. London: Hutchinson and CO LTDA. 244 p.

NADON, MO. and STIRLING, G., 2006. Field and simulation analyses of visual methods for sampling coral cover. Coral Reefs, vol. 25, p. 177-185. http://dx.doi.org/10.1007/s00338-005-0074-5

OLIVEIRA, MIM., 1971. Contribuição ao estudo da malacofauna intertidal de recifes de arenito no nordeste brasileiro. Arquivos de Ciências do Mar, vol. 11, no. 2, p. 83-86.

PEQUENO, APC. and MATTHEWS-CASCON, H., 2001. Predation by young Cassis tuberosa Linnaeus, 1758 (Mollusca: Gastropoda) on Mellita quinquiesperforata (Clarck, 1940) (Echinodermata: Echinoidea), under laboratory conditions. Arquivos de Ciências do Mar, vol. 34, p. 83-85.
PÈREZ, CD., VILA-NOVA, DA. and SANTOS, AM., 2005. Associated community with the zoanthid Palythoa caribaeorum (Duchassaing and Michelotti 1860) (Cnidaria, Anthozoa) from littoral of Pernambuco, Brazil. Hydrobiologia, vol. 548, p. 207215. http://dx.doi.org/10.1007/s10750-005-5441-2

PEREIRA, RC., DONATO, R., TEIXEIRA, VL. and CAVALCANTI, DN., 2000. Chemotaxis and chemical defenses in seaweed susceptibility to herbivory. Brazilian Journal of Biology, vol. 60, no. 3, p. 405-414.

PEREIRA, RC., PINHEIRO, MD., TEIXEIRA, VL. and GAMA, BAP., 2002. Feeding preferences of the endemic gastropod Astraea latispina in relation to chemical defenses of Brazilian tropical seaweeds. Brazilian Journal of Biology, vol. 62, no. 1, p. 33-40. http://dx.doi.org/10.1590/S1519-69842002000100005

REED, JK. and MIKKELSEN, PM., 1987. The molluscan community associated with the scleractinian coral Oculina varicosa. Bulletin of Marine Science, vol. 40, no. 1, p. 99-131.

RICHMOND, RH., 1993. Coral Reefs: present problems and future concerns resulting from anthropogenic disturbance. American Zoologist, vol. 33, p. 524-536.

RIOS, EC., 1994. Seashells of Brazil. 2nd ed. Rio Grande: Fundação Universidade Federal do Rio Grande, Museu Oceanográfico. 368 p.

SALVAT, B., 1967. Importance de la faune malacologique dans les atolls Polynésiens. Cahiers de Pacifiqué, vol. 11, p. 7-49.

-, 1972. Distribution des mollusques sur les recifs exterieurs de l'atoll de Fangataufa (Tuamotu, Polynesie) radiales quantitatives. In Proceedings of the International Coral Reef Symposium, 1972. Lauderdale. p. 373-378.

SHEPPARD, ALS., 1984. The Molluscan Fauna of Chagos (Indian Ocean) and an Analysis of its Broad Distribution Patterns. Coral Reefs, vol. 3, p. 43-50. http://dx.doi.org/10.1007/BF00306139

SIMONE, LRL., 2002. Comparative morphological study and phylogeny of representatives of the superfamily Calyptraeoidea (including Hipponicoidea) (Mollusca, Caenogastropoda). Biota Neotropica, vol. 2, no. 2, p. 1-17.

STENECK, RS. and DETHIER, MN., 1994. A functional group approach to the structure of algal-dominated communities. Oikos, vol. 69, no. 3, p. 476-498. http://dx.doi.org/10.2307/3545860

TAYLOR, JD., 1968. Coral reef and associated invertebrate communities (mainly molluscan) around Mahe, Seychelles. Royal Soc. London. Philosophical Transactions, serie B, vol. 254, p. $129-206$.

-, 1971. Reef associated molluscan assemblages in the western Indian Ocean. Symposia of the Zoological Society of London, vol. 28, p. 501-534.

THOMASSIN, BA. and GANELON, P., 1977. Molluscan assemblages on the boulder tracts of Tulear coral reefs (Madagascar). In Proceedings of the 3nd International Coral Reef Symposium, 1977. Miami. vol. 1, p. 237-252.

VERMEIJ, GJ., 1978. Biogeography and Adaptation: Patterns of marine life. Cambridge: Harvard University Press. 332 p.

WELLS, FE., 2000. Centres of species richness and endemism of shallow water marine molluscs in the tropical Indo-West Pacific. In Proceedings of the 9nd International Coral Reef Symposium, 2000. Bali. vol. 2, p. 23-27. 
ZAR, JH., 1999. Biostatistical Analysis. 4nd ed. New Jersey: Prentice Hall. 663 p.

ZUSCHIN, M. and HOHENGGER, J., 1998. Subtropical coral-reef associated sedimentary facies characterized by mollusks (Nothern Bay of Safaga, Red Sea, Egypt). Facies, vol. 38, p. 229-254. http:// dx.doi.org/10.1007/BF02537367

ZUSCHIN, M., HOHENGGER, J. and STEININGER, FF., 2000. A comparison of living and dead mollusks on coral reef associated hard substrata in the northern Red Sea - implications for the fossil record. Palaeogeography, Palaeoclimatology and Palaeoecology, vol. 159, p. 167-190. http://dx.doi.org/10.1016/ S0031-0182(00)00045-6

-, 2001. Molluscan assemblages on coral reefs and associated hard substrata in the northern Red Sea. Coral Reefs, vol. 20, p. 107116. PMCid:1389613. http://dx.doi.org/10.1007/s003380100140 